\title{
Using Non-native English Films to Promote Multiculturalism in ELT Classroom
}

Nazua Idris

\begin{abstract}
This paper aims to present how the incorporation of non-native English films can enhance the multicultural awareness among the English language learners. As the non-native English films expose the students to linguistic and cultural diversity, they can be used as effective tools in designing materials for ELT classroom. To demonstrate how teachers can incorporate these films in their classroom, the paper discusses various approaches to design materials for language classroom, and contains three sample lesson plans for intermediate, upper-intermediate and advanced level students. The lesson plans exploit a number of non-native English films to generate a discussion of different cultures along with teaching English language. Finally, the paper ends with some suggestions for the teachers.
\end{abstract}

Keywords: Non-native English Films, Multicultural Awareness, Cultural Analysis, Comparative Cultural Analysis, Critical Cultural Analysis

\section{Introduction}

English language teachers around the world have acknowledged the importance of promoting multicultural awareness among language learners. As English language courses are taught almost in all the departments through ESP (English for Specific Purposes) and ESL (English as a Second Language) courses, the language classroom becomes an important platform to teach students about different cultures, and prepare them to cope up with the multicultural scenario of the current world. Due to the rapid growth of information technology, language learning needs are no longer confined to the learning of the native language or culture only. In this age of globalization, it is essential that students develop an awareness of other cultures, and become familiar with the use of English language by non-native speakers in nonnative cultural contexts as learners need to learn to communicate effectively with nonnative speakers of English.

Again, due to the strong influence of Western media, students are constantly being exposed to media contents presenting biased information about different cultures. The students who are exposed to the Western mode of education or exposed to the Western culture only, lack the opportunity to develop adequate understanding of other cultures to judge those biased opinions critically. As a result, due to this gap between the misrepresentation and the reality, the students end up nurturing misconceptions regarding other races, which results in 
xenophobia, race prejudice, and lack of competence in intercultural relationship and communication. Therefore, language teachers should promote discussions on the non-native cultures along with the native culture in their classroom.

ELT practitioners have always encouraged the inclusion of native English films in the language curriculum to enhance learners' competence in the target language and culture. However, in my paper, I will argue how the non-native English films can become important teaching-learning tools in developing positive attitude of the language learners toward other cultures. While the native English films expose the students only to British or American culture, the non-native English films expose them to lifestyles, beliefs, attitudes, human behaviors, and customs of different cultures around the world. A critical analysis of the cultural and linguistic content of such films will not only facilitate students' acquisition of various language skills and intercultural competence, but also trigger their critical thinking. Therefore, this paper discusses various ways of utilizing nonnative films in language classroom. The paper initiates this discussion by exploring the review of the literature on how non-native English films can stimulate multiculturalism among the language learners. Then the paper moves onto a discussion of various approaches of incorporating these films in language curriculum, and includes three sample lesson plans for intermediate, upperintermediate and advanced learners. The paper ends with further suggestions for the teachers and a list of non-native English films.

\section{Non-native English films}

Generally, non-native English films refer to the English films which are produced by the non-native speakers of English, and set in their culture rather than the culture of the native speakers of English. However, there can be variations. Non-native English films include:

1. Films produced by the countries who are non-native speakers of English (the countries outside Britain, Canada, U.S.A and Australia), for example, Bend it Like Beckham (India), Grave of the Fireflies (Japan).

2. Films produced about the people, culture, and behavior of the people who belong to the non-native English speaking communities, for example, Brick Lane (Britain).

3. Films which are the adaptations of non-native English fictions or drama, for example,The Kite Runner (written by Afgan-American writer Khaled Hosseini, produced in America by director Marc Forster).

4. Non-native films which may not be produced in English language but culturally rich and available with English subtitles, for example, Bekas (Kurdish), Osama (Persian).

\section{Literature review}

\section{Multiculturalism in English language teaching}

Multiculturalism refers to cultivating an awareness regarding the cultural diversity across the world. This awareness does not only mean knowing about different cultures but also mean having sensitivity about other cultures. Various researchers have defined this awareness in different ways. Sinicrope, Norris and Watanabe (2007) see this awareness as an "ability to step beyond one's own culture and function with other individuals from linguistically and culturally diverse background" (p. 1). Similarly, Fantini (2006) says that multicultural awareness involves "a complex of abilities needed to perform effectively and 
appropriately when interacting with others who are linguistically and culturally different from oneself" (p. 12).

Nurturing such consciousness about other cultures is important for living in this $21^{\text {st }}$ century multicultural world. Shemshadsara (2012) identifies the need for strong multicultural understanding in a language classroom because of the "recent development both nationally and internationally" (p. 95). Chlopek (2008) also stresses on the impact of promoting crosscultural awareness in this globalized world, and suggests that by developing such an awareness learners can "benefit by gaining solid knowledge of the different world cultures, and . . . develop the ability to compare their native culture to other cultures, to evaluate critically and interpret the results of such comparisons, and to apply this knowledge successfully in both verbal and non-verbal communication" (p. 12).

Hence, cultivating multicultural awareness should be the goal of contemporary education as it is essential for peaceful coexistence and intercultural exchanges. According to Hadley (1993), for a harmonious existence, learners need to have multicultural awareness and sensitivity, promoted through educational materials. Stratiem (1981, cited in Hadley, 1993) recognizes the importance of cultural sensitivity and global understanding in terms of language education, and asserts that such sensitivity can be achieved through the successful integration of various cultures into language teaching which will result in a greater understanding of humanity. Stern (1992) suggests that language learners can achieve more proficiency by "becoming sensitive to the state of mind of individuals and groups within the target language community" (p. 217).
Therefore, the most important goal of multicultural education is to liberate the minds of the learners from the biased notions about the people of other cultures. The best way to achieve this goal is to make learners aware of the common ties they share with other cultures, and encourage them to appreciate the differences. Wieto (2010, cited in Shemshadsara, 2012) recognizes the significance of promoting cultural sensitivity in the classroom to help students come out of their narrow judgmental ideas and prejudices about the people of other countries. Likewise, Tomlinson (2001, cited in Tomlinson and Masuhara, 2004) makes an important observation that if the multicultural awareness is cultivated in a language classroom, learners gradually realize the underlying similarity among the cultures, develop a sense of equality, attain a greater level of comprehension regarding their own culture, cultivate a positive attitude toward other cultures, and become more tolerant toward cultural diversity. In a similar vein, Knuston (2006, cited in Beaudrie et al., 2009) also states the importance of crosscultural awareness in making the learners understand their own cultural identity in relation to the people from other cultures. The formation of identity through such intercultural exchange creates a sense of equality in the learners which is the goal of multiculturalism.

\section{Using non-native English films to promote multiculturalism}

Non-native English films can become effective tools to enhance multicultural awareness among the language learners. These films are rich in cultural content, such as linguistic variety, speech patterns, cultural concepts, verbal and non-verbal behavior, local history, tradition, geography, environment, customs, festivals, religious and social beliefs, sociopolitical and economic structure, superstitions, taboos and so on. Thus, these 
films familiarize learners with the contextual variables of language use in different cultural locations. Lottmann (1961) suggests that as films "present the cultural, historical and geographical background . . . [they] are [the] most important aid in the dispelling of misunderstandings in that aspect of language study . . . [offering] an authentic picture presented in an authentic context . . . universally understood" (p. 178). Lottmann (1961) further says that films can ensure greater understanding of a holistic cultural scenario "including regional dialects; the learning of social formulas, sentence structure, intonation patterns, new vocabulary, geographical and historical facts of the country, contemporary life with attention to family attitudes, education, religion or government" (p.178).

Stressing on the diversity of content in multicultural films, Hill (1999) suggests that "no teacher alone can reproduce the variety of situations, voices, accents, themes and presentation techniques that are a feature of this [film] medium" (p. 2). In a similar manner, Prathoomthin (2009) also suggests that films "can provide insightful learning experiences on the language and cultures . . . which students might be unlikely to have in a classroom" (p. 291). Rogers (2002) states that "Movies serve not only as powerful socialising agents in society, but serve as vehicles where we can share and we can solve the problems. We can come together to discover new ways of being, doing, and, learning. Movies yield an opportunity to explore and examine adult learning in the social context" (p. 327).Turner (1999) also recognizes the value of films as cultural documents, as the socio-political movements, history and other aspects of a particular culture are illustrated in its films. In addition to the contextual variety, Kaiser (2011) stresses on the linguistic variety presented in these films, and observes that "the spoken language of film often incorporates a wide variety of sociolects of the target language, e.g., the speech of various socio-economic and educational levels, the speech of children and non-native speakers, slang and jargon, rural and urban speech, and a range of regional dialects" (p. 233). Films not only include linguistic features, but also include extra-linguistic elements like non-verbal gestures and facial expressions that reinforce learners' comprehension of a language in context (Allan, 1985).

Again, inclusion of non-native films in the language curriculum can help learners come out of their misconceptions about other races. Kaiser (2011) suggests that these movies can be used to "debunk common stereotypes" (p. 245) presented in Western films. Yalcin (2013) also finds the inclusion of films helpful in "eradicate[ing] stereotypes . . . to promote intercultural understanding, universally shared values and human rights" (p. 260). In a similar vein, Kusumarasdyati (2006) suggests that films can help dissolve the "cross-cultural misunderstanding" (p. 2) by creating empathy in learners for other cultures. Likewise, Kramsch (1993) maintains that films expose students to a wide range of contextual variables; give philosophical insights into the human predicament; and helps students restructure their previous knowledge system in the light of new insights, gained from their constant interaction with other cultures. Moreover, constant exposure to the cultural variety involves students in an intercultural dialogue where students perceive their own cultural identity in relation to the other cultures. Prathoomthin (2009) suggests that such an attitude makes learners "ready to consider others in a more favorable light" ( $p$. 291).

Through these non-native films learners not only get to know about other cultures but develop a sensitivity and insight into the why and how behind the cultural diversity around the world. These insights create empathy in 
the minds of learners. Istanto (2009) considers film as "an effective platform" that allows students to "immerse themselves in the target culture, broaden their geographical knowledge . . . observe the socio-linguistic, socio-economic, sociopolitical, and educational issues in the target community . . . deepen their understanding of moral values of the target language . . . and stimulate empathy towards the target community" (p. 278). In such a learning environment, learners become motivated to take the charge of their own learning. According to Wang (2009):

[Films give students such] audio-visual environments . . . [that] the students can never wait to be "fed" by teachers, they will try their best to move into the target languages, and to search for various different cultures, information such as how . . . the speakers behave and interact with each other; their values on all things, customs, housing, clothing and even food. Owing to the rich contextual setting available, students can adopt spontaneous way of learning, learn to think and to widen their scope of knowledge outside of the textbooks which form the process of large new information receiving and intensified patterns. (p. 180)

Thus, as non-native English films explore English language in various cultural contexts, they can offer us an "alternative way to work with language and culture in context" (Harrison, 2009, p. 89).

\section{Material design}

\section{Approaches}

While designing materials for language classroom, the following approaches can be used:
1. Cultural analysis. This approach refers to an intensive analysis of the cultural content of one particular film. It helps students have deeper understanding of the lifestyle, behavior, customs and beliefs of that culture. This approach is suitable for designing tasks for the pre-intermediate and intermediate level students.

2. Comparative cultural analysis. In this approach, two or more films from different countries are taken and tasks are designed to generate comparative discussions of various cultures. This approach will help students understand the cultural diversity as well as the underlying similarity between different cultures. This approach is suitable for the upperintermediate level students.

3. Critical cultural analysis. This approach is for the advanced level students. This approach takes a critical look at the cultural content of films. It also invites learners to critically analyze the representation of one culture by another, and helps students comprehend the issue of stereotyping and misrepresentation. As often there are inaccuracies and biased opinions in the West's representation of other countries, we can choose films made in the West and films made in the other countries based on the same issue, to draw students' attention to the incongruous information presented in these films. For example, Pearl Harbor and Tora Tora Tora can be used for such an analysis as the first one represents the American interpretation of the incident in Pearl Harbor during the World War II, and the second one presents the Japanese interpretation of the same event. 


\section{Rationale for movie selection}

I have selected five movies from Japan, Iran, India, Italy and Afghanistan. The films are: Grave of the Fireflies (Japan), Children of Heaven (Iran), Like Stars on Earth (India), Bicycle Thieves (Italy), and Osama (Afghanistan). Grave of the Fireflies revolves around the story of the children of a dead Japanese soldier during the World War II, and presents a picture of the condition of Japanese children during the war. Children of Heaven is the story of two siblings and a pair of shoes, and deals with the hardships and dreams of the Middle Eastern lower class children. Like Stars on Earth revolves around the story of a young boy's hardships in coping with the resultbased education system that ignores the hidden potentials of the children, and deals with the issue of child education. Bicycle Thieves deals with the wretched condition of the poor people in post-World War II Europe. Osama represents the plights of women under Talibaan rule through the constant struggle of a pre-teen girl to hide her gender identity and her ultimate failure and punishment into a forced matrimony.

All these films share similar themes, for example, tragedy of human life, dreams and aspirations, beauty of relationships, predicament of the children in war-stricken societies, socio-political and historical landscape of the respective cultures, war and destruction, and so on. These films can draw students' attention to the underlying similarity regarding the plights of people across cultures, and uphold the universal struggle of human beings for existence. The shorter length, quick-moving plot, simple narrative with rich socio-cultural and historical content and deeper cultural and philosophical insights have made these films effective tools to be used in teaching culture. Moreover, these films have lesser amount of dialogue and meaning is conveyed through landscape, imagery and other extralinguistic features which make these films exploitable for designing activities to improve critical comprehension of other cultures.

\section{Activities}

\section{Intermediate Level}

Film: Grave of the Fireflies

Approach: Cultural Analysis

\section{Pre-viewing Activities}

Task 1. What do you think about these pictures? Describe the images in your own words.

Photographs. www.googleimages.com.

Task 2. What do you know about the World War II?
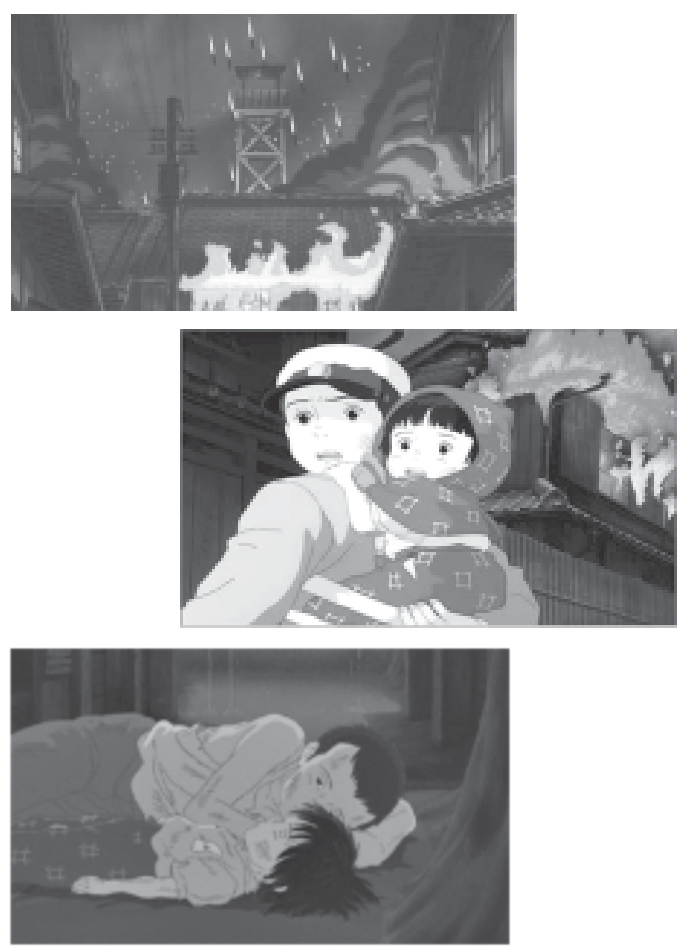
Rationale. Task 1 and 2 are meant to activate the schema of students. These tasks will also help them guess the major themes of the film and its historical background. Thus, from the very beginning, students will be engaged in a discussion about the cultural content of the film.

\section{While-viewing activity}

Task 1. Watch the clips. While viewing the clips, fill up the following chart:

Chart 1.Cultural analysis

\begin{tabular}{|l|l|}
\hline Points & Grave of the Fireflies \\
\hline Characters & \\
\hline Relationships & \\
\hline Dress & \\
\hline Food & \\
\hline Customs & \\
\hline Class & \\
\hline Landscape & \\
\hline Historical References & \\
\hline Message & \\
\hline Others & \\
\hline
\end{tabular}

Rationale.This task will keep students alert to the cultural clues embedded in these clips. As all the cultural aspects are not directly shown in these clips, learners will haveto use their critical judgment to find out information about the points of the chart.

\section{Post-viewing activities}

Task 1.From your experience of viewing Graves of the Fireflies, write about the condition of Japanese children during the World War II.

Task 2. What are the similarities or differences between the condition of poor children in Japan and your country?
Task 3. What do you find about the brothersister relationship in Japan? Do you find any similarity between your country and Japan in this regard?

Rationale.These tasks will enable students to achieve a greater understanding about Japanese history and culture, especially, during the war. The tasks are designed in such a way that they gradually move from an analysis of one culture to a comparative analysis between the target culture and the learner's native culture. Such an approach helps learners nurture multicultural awareness, and draw a parallel between their own culture and the target culture, and grow a sense of empathy toward others.

\section{Upper-intermediate level}

Film: Grave of the Fireflies, Bicycle Thieves, Like Stars on Earth and Children of Heaven

Approach: Comparative cultural analysis

\section{Pre-viewing activity}

Task 1. Look at the images below. Why do you think these children are depressed? Chose a reason from below and match with the images. Give reasons for your choice.

\section{Poverty \\ Failure \\ War}

Broken-promise

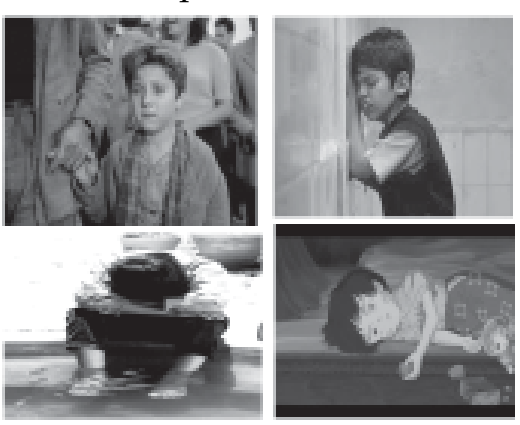

Photographs. www.googleimages.com. 
Task 2. Can you guess the nationality of these characters from their appearance? You can take help from the list below:

$\begin{array}{ll}\cdot \text { Indian } & \text { Italian } \\ \cdot \text { Iranian } & \cdot \text { Japanese }\end{array}$

Rationale. These pre-viewing tasks will activate the schema of learners. These tasks will engage the learners in a comparative discussion of the socio-cultural background before they move onto the while-viewing stage. The clues will give learners insights into the predicament of the characters of these films. As students need to decode the visual clue to give their interpretation, they will have to apply their prior knowledge along with critical thinking ability.

\section{While-viewing activity}

Task 1 . Watch the clips. While viewing the clips, fill up the following chart:

Chart 2. Comparative cultural analysis

\begin{tabular}{|l|l|l|l|l|}
\hline \multicolumn{1}{|c|}{ Points } & Grove of the & Bicycle & Like Stars & Children of \\
\hline Characters & & & & \\
\hline Relationship & & & & \\
\hline Dress & & & & \\
\hline Food & & & & \\
\hline Customs & & & & \\
\hline Class & & & & \\
\hline Landseape & & & & \\
\hline Historieal & & & & \\
\hline Referenees & & & & \\
\hline Message & & & & \\
\hline
\end{tabular}

Rationale. This simple chart-filling activity will make the student conscious about the cultural elements of the movies. This comparative chart will help students have an instant insight into the similarities and dissimilarities between the cultures of the respective countries.

\section{Post-viewing activity}

Task 1. From your experience of viewing the clips, compare the lives of children in different parts of the world. In your presentation, bring out the similarities and differences. How far do you think the life of the children of your country is similar or dissimilar to these children?

Rationale. This task applies the comparative cultural analysis approach where students will have to compare the cultural aspects of different countries presented in the movies. This task will enhance the cross-cultural understanding of learners. In the second portion of the task, they are required to compare the target cultures with the culture of their own country which will enable them to understand the underlying resemblance between different cultures, while the minute details from the chart will help them recognize the cultural diversity.

\section{Advanced Level}

Film: Grave of the Fireflies, Bicycle Thieves, Like Stars on Earth, Children of Heaven and Osama

Approach: Criticalcultural analysis

Pre-viewing activity

Task 1. Watch the clips (without any sound). What do you think these clips are about? Write a small dialogue for each clip.

Rationale. This task requires a higher level of linguistic competence and critical thinking ability on the part of the learner as they will have to analyze the visual clues before they have any idea about the films, and then, come up with the dialogue themselves. This task will activate the student's prior knowledge and motivate them to work on it.

\section{While-viewing activity}

Task 1 . Watch the clips again (with sound). While viewing the clips, compare your 
imagined dialogues with the dialogues of the clips.

Rationale. This task will enable the student to critically compare their insights with the real dialogue presented in the films. This activity will draw their attention to the gaps they have in their understanding of other cultures, and will allow them to restructure their prior knowledge in the light of the new information they have gathered from their second viewing.

\section{Post-viewing activity}

Task 1 . From your experience of watching the clips, write an essay discussing how the characters perceive their world differently due to the difference of their cultural identity.

Task 2. If you are asked to shoot one of these films in your cultural context, what are the elements that you are going to retain and what are the elements that you will alter? Give reasons for your answer.

Rationale. These tasks will allow learners to apply their critical insights in interpreting the characters in various cultural contexts, and facilitate their comprehension of why and how the behavior of the people changes with the changing cultural landscape. Moreover, Task 2 will enable the learner to explore their creative writing ability along with their critical thinking skills.

A number of other films can be used, as described above, in the English language classroom. Here is a suggested list:

\section{For Intermediate/ Upper-intermediate Learners}

I am Kalam (India)

Bend It Like Beckham (India)
Bekas (Kurdish)

The Color of Paradise (Iran)

About Elly (Iran)

Life Is Beautiful (Italy)

The Bicycle Thief (Italy)

Princess Mononoke (Japan)

\section{For Advanced Level Learners}

The Kite Runner (America)

Pearl Harbor (America)

Tora Tora Tora (Japan)

Memoirs of Geisha (Japan)

Baran (Iran)

The Last Emperor (China)

Osama (Persian)

Turtles Can Fly (Kurdish)

Brick Lane (Britain)

Midnight's Children (Britain-Canada)

\section{Limitations of using films}

There are some limitations of using films in the classroom. In case of using non-native films in other languages, as students need to pay more attention to find out the coherence between the visual details and the subtitle, time-management creates a problem for teachers. Again, watching an entire movie takes a longer time to complete compared to other language activities (Ismaili, 2013). Therefore, the use of films can prove to be counter-productive as students may get lost in the storyline, and if the teacher is not conscious, the goal of using these films may become futile (Muller, 2006). Similarly, designing materials from films is also time-consuming for the teacher as they have to work a lot for choosing proper films for their classroom, analyzing the texture of the films and their cultural contents, and 
designing appropriate materials to make the unfamiliar cultural contents comprehensible for their students. Again, the contextual and linguistic variety can be overwhelming for teachers if they have less exposure to the culture concerned. According to Anderson (1992) there are risks in using films because the sociocultural-political ideas represented in the films can be partial or distorted. As a result, if the teacher is not aware of the culturally specific visual semiotics of the film and their subtle ideological representations, students may form biased opinions about a particular culture. Moreover, there are some administrative restraints regarding using films for classroom. Due to insufficient logistic support, time constraint and strict adherence to the traditional testing methods, it is not possible to use films to design conceptual or critical activities for evaluating cross-cultural competence during the examination. As a result, the administration often discourages the use of films nurturing the prejudice that inclusion of films in language teaching curriculum is wastage of time. Harrison (2009) states, "the wide array of approaches, ideas, and materials for teaching culture unfortunately is not matched by effective ways of testing" (p. 92). He further suggests that a lack of incentive during the examination can also demotivate learners in studying films in the language classroom.

\section{Conclusion}

In short, the inclusion of non-native English films offers an enriching cultural experience to language learners. While the sole use of native English films limit the socio-cultural and linguistic vision of students, inclusion of non-native films familiarizes students with various aspects of a culture along with language variety. As tertiary students are more mature, blending of native and non-native films can generate a critical intercultural dialogue resulting in greater comprehension of a culture. Inclusion of these films will not only enhance the intercultural competence but also improve a number of other skills, such as listening, critical viewing, critical thinking, critical and creative writing, media literacy, visual literacy and so on. However, the successful implementation of films in designing materials lies in the hands of the teacher.

To deal with the time-constraint, the teacher can ask their students to watch the selected films at home, and show the important clips related to the activities in the classroom. Kaiser (2011) suggests that the institutions where there is a language laboratory or computer laboratory, the important films can be saved there so that the students have access to them outside the classroom. To ensure appropriacy of the films, the teacher needs to be very careful in their choice of films. Though it requires a lot of hard work on the part of the teacher, they must watch the films, and select and categorize wisely based on the age-group, intellectual maturity and socio-culturalpolitical background of their students, cultural appropriacy and the level of linguistic and thematic complexity. Again, teachers can design different while-viewing activities, for example, a small discussion after each major section is viewed, quiz, fillin the blanks, short critical questions etc., so that they are always conscious about their learning objective. To make the intricate ideas clear, the teacher can provide their students with a list of critical concepts and vocabulary related to the films so that students can easily identify the theme and context of the films, especially in case of the non-native films produced in local languages. When students become aware of the background, it will be easier for them to follow the language of the nonnative films. To cope with the scarcity of logistic support, teachers can provide their students with the script of the movie, and 
discuss the cultural ideas presented in the dialogue. The teachers can also prepare posters using still images from the movies to present important ideas if their classroom does not have enough logistic support to play the videos.

\section{About the Author}

Nazua Idris is a Lecturer at East West University, Bangladesh. Her research interests are film studies, teacher education and ELT. She has presented twenty papers in various international conferences. She has conducted teacher training workshops in BRAC, Scholastica, SPEED and ELTAI Conference. Seven of her papers have been published in scholarly journals.

\section{References}

Allan, M. (1985). Teaching English with video. Essex: Longman.

Anderson, D. D. (1992). Using feature films as tools for analyst in psychology and law course. Teaching of Psychology, 19(3), 155-158.

Beaudrie, S., Ducar, C., \& Relano-Pastor, A. M. (2009). Curricular perspective in the heritage language teaching: Assessing, culture and identity. Language, Culture and Curriculum, 22(2), 157-174.

Chlopek, Z. (2008). The intercultural approachto EFL teaching and learning. English Teaching Forum, Number 4, 10-27.

Fantini, A. E. (2006). Exploring and assessing intercultural competence. Retrieved from, http://www.sit.edu/ $\mathrm{p} \mathrm{u} \mathrm{b} \mathrm{l} \mathrm{i} \mathrm{c} \mathrm{a} \mathrm{t} \mathrm{i} \mathrm{o} \mathrm{n} \mathrm{s} \mathrm{/} \mathrm{d} \mathrm{o} \mathrm{c} \mathrm{s} \mathrm{/}$ feil_research_report.pdf
Hadley, A. O. (1993). Teaching language in context. Boston: Heinle and Heinle Publishers.

Harrison, L. G. (2009). Foreign films in the classroom: Gateway to language and culture. Journal of College Teaching and Learning, 6(8), 89-93.

Hill, B. (1999). Video in language learning. Video Tech, 4(1), 1-58.

Ismaili, M. (2013). The effectiveness of using movies in the EFL classroom - A study conducted as South East European University. Academic Journal of Interdisciplinary Studies, 2(4), 121-132. doi:10.5901/ajis.2012.v2n4p121.

Istanto, J. W. (2009). The use of films as an innovative way to enhance language learning and cultural understanding. Electronic Journal of Foreign Language Teaching, 6(1), 278-290. Retrieved from, http:/ /e-flt.nus.edu.sg/

Kaiser, M. (2011). New approaches to exploring film in the foreign language classroom. L2 Journal, 3(2), 232-249.

Kramsch, C. (1993). Context and culture in language teaching. Oxford: Oxford University Press.

Kusumarasdyati. (2006). The use of movie videos to enhance cross-cultural understanding. Paper presented at the $16^{\text {th }}$ Biennial Conference of the Asian Studies Association of Australia, Wollongong.

Lottmann, M. A. (1961). Films in the modern language class. The Modern Language Journal, 45(4), 178-180.

Muller, V. (2006). Film as film: Using movies to help students visualize literary theory. The English Journal, 95(6), 32-38. 
Prathoomthin, S. (2009). Learners' perceptions of culture through movies. Electronic Journal of Foreign Language Teaching, 6 (1), 291-301. Retrieved from, http:/ /e-flt.nus.edu.sg/

Rogers, E. E. (2002). Waiting to exhale: African American women and adult learning through movies. Paper presented at the 33rd Annual Adult Education Research Conference (AERC), Saskatoon, Saskatchewan, Canada. Retrieved from, http:// www.adulterc.org/Proceedings / 2002/ papers/Rogers.pdf

Shemshadsara, Z. G. (2012). Developing cultural awareness in foreign language teaching. English Language Teaching, 5(3), 95-99. Retrieved from, www.ccsenet.org/elt

Sinicrope, C., Norris, J., \& Watanabe, Y. (2007). Understanding and assessing intercultural competence: A summary of theory, research, and practice (technical report for the foreign language program evaluation project).
Second Language Studies, 26(1), 1-58. Retrieved from,http:/ / www.hawaii.edu/sls/uhwpesl/ $26 \% 281 \% 29 /$ Norris.pdf

Stern, H. H. (1992). Issues and options in language teaching. Oxford: Oxford University Press.

Tomlinson, B., \& Masuhara, H. (2004). Developing cultural awareness. MET, 13(1), 1-7.

Turner, G. (1999). Film as social practice (3rd ed.). London: Routledge.

Wang, Y. (2009). Using films in the multimedia English class. English Language Teaching, 2(1), 179-184. Retrieved from, www.ccsenet.org/ journal.html

Yalcin, N. (2013). Using movies in language classrooms as means of understanding cultural diversity. Epiphany: Journal of Transdisciplinary Studies, 6(1), 259271. 